\title{
EVALUATION OF PUSPA AGRO CENTRAL BUSINESS MARKET LOCATION IN EAST JAVA PROVINCE USING CENTER GRAVITY MODEL
}

\author{
Ahmad Faathir Wicaksono ${ }^{1}$, Ratna Handayani ${ }^{2}$ \\ ${ }^{1,2}$ Road and Bridge Engineer, East Java Province Road Agency, Surabaya, Indonesia \\ e-mail: faathirahmad@gmail.com
}

\begin{abstract}
The Puspa Agro central business market was built to increase the food supply as well as shortened the supply chain to elevate the farmer income and in the large scale escalating the economic growth of East Java Province. Meanwhile, the central market operational activity did not work as expected as planned and the government initiates to upgrading the accessibility toward the Puspa Agro central market by constructing a new road connecting with the toll road directly the arterial road. The main purpose of this research is to evaluate the location of Puspa Agro central business market using the center gravity model. The research shows that the location of Puspa Agro central business market is not fulfilling the requirement based on the 3 (three) approach which are the location of people an $d$ goods mobility, the location of agriculture production such as, fishery, fruit and vegetables and the number of the population of the nearest city. The three alternates location is proposed, at Waru and Candi districts in Sidoarjo City and near the Pasuruan City. The alternate location must be considered to rise the central business market income since the existing location was not fully capable to achieve the trading transaction.
\end{abstract}

Keywords: Central Businnes Market; Center Gravity Model; Alternate Location; Warehouse

\section{Introduction}

The Puspa Agro central business market was built in 2008 in order to increase the food supply as well as shortened the supply chain to elevate the farmer income and in the large scale escalating the economic growth of East Java Province. Puspa Agro is managed with the concept of integrating various agro products in one well-organized area [1] [2] and to be developed as agribis market [3] . Meanwhile, the central market operational activity did not work as expected as planned with the low occupancy rate of shop booth and the minimum of trading transaction, there are only 5 booths operated from total 1045 booths offered [4]. At 2020, the Puspa Agro central market did not make adequate contributions and profit with the total loss around 1 billion [5]. The main problem which causing the slack of the market was the congestion of road access both in and out as well as the competition with other market which offering the competitive price [6]. The road congestion often occurs on Kletek Taman Sidoarjo [7] as the only road access toward the central market [8]. To support the Puspa Agro central market, the government had been issued the regulation of the development acceleration in East Java Province through The Government Regulation Number 80 year 2019 in order to increase the accessibility toward the Puspa Agro central market by constructing a new road connecting with the toll road directly the arterial road [9].

The ultimate purpose of the research is to evaluate the location of the Puspa Agro central market using the center gravity model as the alternative solutions on the decision of government policy. The right choice of the market location is important affecting the logistic cost which can impact the market occupancy, and also because one of the keys to a company's success is to be able to win the competition market lies in good supply chain management [10]. 


\section{Material and Methods}

\subsection{Center Gravity Model}

Center gravity location model is the moderate model as the part of the strategy to develop the supply chain network management which can be used to determine the effective location of certain new facility such as the warehouse [11], factory and central market connecting the supply sources from a different location. The gravity model is widely used to determine the optimum location, the previous research had been undertaken by Mawadati, et.al (2020) which researching the location of the PT Aneka Adhi logam Karya location in Yogyakarta [12]. The research using the gravity model had also been used by Ama, et.al (2015) to determine the optimum location of food barn in South East Minahasa District [13] and determining the distribution network [14]. The gravity model was also used to formulate the optimum location for the warehouse had been conducted by Soesilo R, et.al (2020) for PT. RPZ project in Surabaya [15]. The economic analysis for religion tourism area in Semarang using gravity model and network analysis had been studied by Putri W H, et.al (2021) based on the number of population of the nearest districts [16]. The ideal location is the location which resulting the minimum distance between the warehouse and the retailer outlets, the distance is weighted based on the number containers carried. The formula of Center Gravity Model [17] is shown below:

$$
\begin{gathered}
C_{x}=\frac{\sum_{i} d_{i x} W_{i}}{\sum_{i} W_{i}} \\
C_{y}=\frac{\sum_{i} d_{i y} W_{i}}{\sum_{i} W_{i}}
\end{gathered}
$$

Where:

$\mathrm{Cx}=$ Coordinate $\mathrm{x}$ from the center of gravity

$\mathrm{Cy}=$ Coordinate $\mathrm{y}$ from the center of gravity

$\mathrm{d}_{\mathrm{ix}} \quad=$ Coordinate $\mathrm{x}$ from location $\mathrm{i}$

$\mathrm{d}_{\mathrm{iy}} \quad=$ Coordinate $\mathrm{y}$ from location $\mathrm{i}$

Wi $=$ Good Volume which had been transported from location $\mathrm{i}$

\subsection{Research Method}

The evaluation of the Puspa Agro central market location using the centre gravity model is the mathematical numerical approach based on the coordinate which will be compared with the existing market location. The research is used three alternative approach based on the goods and people transported as follows:

- The location of people and goods mobility,

- The location of agriculture production such as, fishery, fruit and vegetables

- The Number of the population of the nearest city

Table 1. The reference coordinate of each approaches

\begin{tabular}{|c|l|c|c|c|}
\hline \multirow{2}{*}{ No. } & \multicolumn{1}{|c|}{ Model Approach } & \multirow{2}{*}{$\begin{array}{c}\text { Reference } \\
\text { Location }\end{array}$} & \multicolumn{2}{|c|}{ Reference Coodinate } \\
\cline { 4 - 5 } & & E & $\mathrm{N}$ \\
\hline 1 & The location of people and goods mobility & Tulangan, Sidoarjo & 112,65 & $-7,46$ \\
\hline 2 & $\begin{array}{l}\text { The location of agriculture production } \\
\text { such as, fishery, fruit and vegetables }\end{array}$ & Wlingi, Blitar & 112,32 & $-8,12$ \\
\hline 3 & $\begin{array}{l}\text { The Number of the population of the } \\
\text { nearest city }\end{array}$ & Wlingi, Blitar & 112,32 & $-8,12$ \\
\hline
\end{tabular}

Source: Calculation, 2021 


\section{Result and Discussion}

The evaluation of the Puspa Agro central market location based on the location of people and goods mobility is using the nearest station or airport which can describe the optimum central market location servicing the nearest people and goods mobility which can both reducing the transportation cost and gaining more access from and toward the location of central market. The nearest of the station was Bungurasih, Larangan Bus Station in Sidoarjo and Gubeng Train Station in Surabaya. The nearest airport was the Juanda Internation Airport in Sidoarjo.

Table 2. Coodinate of Proposed Location Based on the Location of People and Goods Mobility

\begin{tabular}{|c|c|c|c|c|c|c|}
\hline Location & $X(E)$ & Coordinate & $\mathrm{Y}(\mathrm{N})$ & Coordinate & $\begin{array}{l}\text { Passengers } \\
\text { (Year) }\end{array}$ & $\begin{array}{l}\text { Passengers } \\
\text { (Month) }\end{array}$ \\
\hline $\begin{array}{l}\text { Reference Location } \\
\text { (Tulangan) }\end{array}$ & 112,65 & 0,00 & $-7,46$ & 0 & & \\
\hline Bungurasih Bus Station & 112,72 & 0,07 & $-7,35$ & 0,11 & 33231163 & 2769263,58 \\
\hline Larangan Bus Station & 112,72 & 0,07 & $-7,45$ & 0,01 & 760000 & 63333,33 \\
\hline Juanda Airport & 112,79 & 0,14 & $-7,38$ & 0,08 & 6800000 & 566666,67 \\
\hline Gubeng Train Station & 112,75 & 0,10 & $-7,26$ & 0,2 & 2500000 & 208333,33 \\
\hline Puspa Agro & 112,68 & 0,03 & $-7,37$ & 0,09 & & \\
\hline Proposed Location & 112,73 & 0,08 & $-7,35$ & 0,11 & & \\
\hline
\end{tabular}

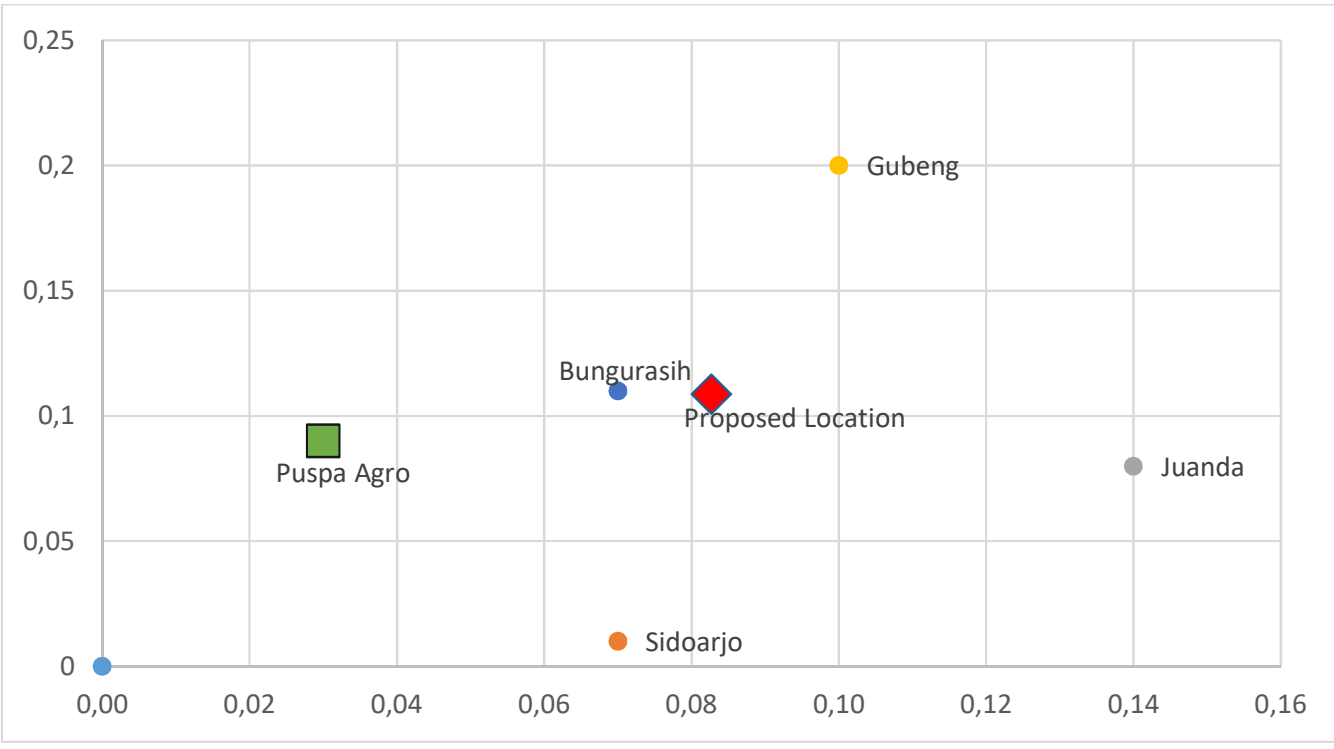

Figure 1. The Proposed Location of Central Market Based on The Location of People and Goods Mobility

The proposed location of Puspa Agro central market based on the the location of people and goods mobility is expected near the Waru in Sidoarjo City (Figure 1) where the existing location of the market is far from the Bus Station. The result is appropriate since many service and trading such as car dealer, bank and food strores operate along the main arterial road at Ahmad Yani Road as well as close to the exit toll road Surabaya to Sidoarjo and Surabaya to Mojokerto to give an easy access for transporting people and goods. The second approach to evaluate the location of Puspa Agro 
central market is based on the on the location of agriculture production such as, fishery, fruit and vegetables. The closer the locaton of the market with agriculture production the easier and the less cost spent for logistics and transportation for goods.

Tabel 3. Coordinate Proposed Location Based on the Location of Agriculture Production Such as,

Fishery, Fruit and Vegetables

\begin{tabular}{|c|c|c|c|c|c|}
\hline Location & $X(E)$ & Coordinate & $\mathrm{Y}(\mathrm{N})$ & Coordinate & $\begin{array}{l}\text { Fish, Fruit and } \\
\text { Vegetables } \\
\text { Production } \\
\text { (Ton) }\end{array}$ \\
\hline $\begin{array}{l}\text { Reference Location } \\
\text { (wlingi blitar) }\end{array}$ & 112,32 & 0 & $-8,12$ & 0 & \\
\hline Mojokerto & 112,43 & 0,11 & $-7,47$ & 0,65 & 66986 \\
\hline Sidoarjo & 112,69 & 0,37 & $-7,44$ & 0,68 & 15752 \\
\hline Pasuruan & 112,88 & 0,56 & $-7,65$ & 0,47 & 1313754 \\
\hline Lawang & 112,69 & 0,37 & $-7,83$ & 0,29 & 26136 \\
\hline Surabaya & 112,72 & 0,4 & $-7,26$ & 0,86 & 8300 \\
\hline Gresik & 112,62 & 0,3 & $-7,16$ & 0,96 & 53843 \\
\hline Lamongan & 112,41 & 0,09 & $-7,10$ & 1,02 & 128963 \\
\hline Puspa Agro & 112,68 & 0,36 & $-7,37$ & 0,75 & \\
\hline Proposed Location & 112,88 & 0,56 & $-7,59$ & 0,53 & \\
\hline
\end{tabular}



Figure 2. The Proposed Location of Central Market Based on The Location of Agriculture Production Such As, Fishery, Fruit and Vegetables

The location of central market based on the location of agriculture production such as, fishery, fruit and vegetables lays near the Pasuruan City where the Pasuruan is the biggest contributor for agriculture product such as fruit, vegetables and fishery in East Java Province. The proposed location near Pasuruan City is expected to reduce the logistics cost and stored time saving make the product 
is quickly absorbed by the people at the fresh condition. The Pasuruan to Probolinggo toll road has been operated making the access and transportation for goods is easier. The latest approach which will be used is based on the number of population of the nearest city which can affecting the investment decision regarding to the number of people doing the trading transaction. The nearest city with the existing central market was Surabaya, Mojokerto, Gresik, Lamongan, Pasuruan and Malang.

Tabel 4. Coordinate Proposed Location Based on the Number Population of the Nearest City

\begin{tabular}{|c|c|c|c|c|c|}
\hline Location & $X(E)$ & Coordinate & $\mathrm{Y}(\mathrm{N})$ & Coordinate & Population \\
\hline $\begin{array}{l}\text { Titik Acuan (wlingi } \\
\text { blitar) }\end{array}$ & 112,32 & 0 & $-8,12$ & 0 & \\
\hline Mojokerto & 112,43 & 0,11 & $-7,47$ & 0,65 & 1108718 \\
\hline Sidoarjo & 112,69 & 0,37 & $-7,44$ & 0,68 & 2216804 \\
\hline Pasuruan & 112,88 & 0,56 & $-7,65$ & 0,47 & 1616578 \\
\hline Malang & 112,63 & 0,31 & $-7,96$ & 0,16 & 2591795 \\
\hline Surabaya & 112,72 & 0,4 & $-7,26$ & 0,86 & 2885555 \\
\hline Gresik & 112,62 & 0,3 & $-7,16$ & 0,96 & 1299024 \\
\hline Lamongan & 112,41 & 0,09 & $-7,10$ & 1,02 & 1188913 \\
\hline Puspa Agro & 112,68 & 0,36 & $-7,37$ & 0,75 & \\
\hline Proposed Location & 112,74 & 0,42 & $-7,47$ & 0,65 & \\
\hline
\end{tabular}

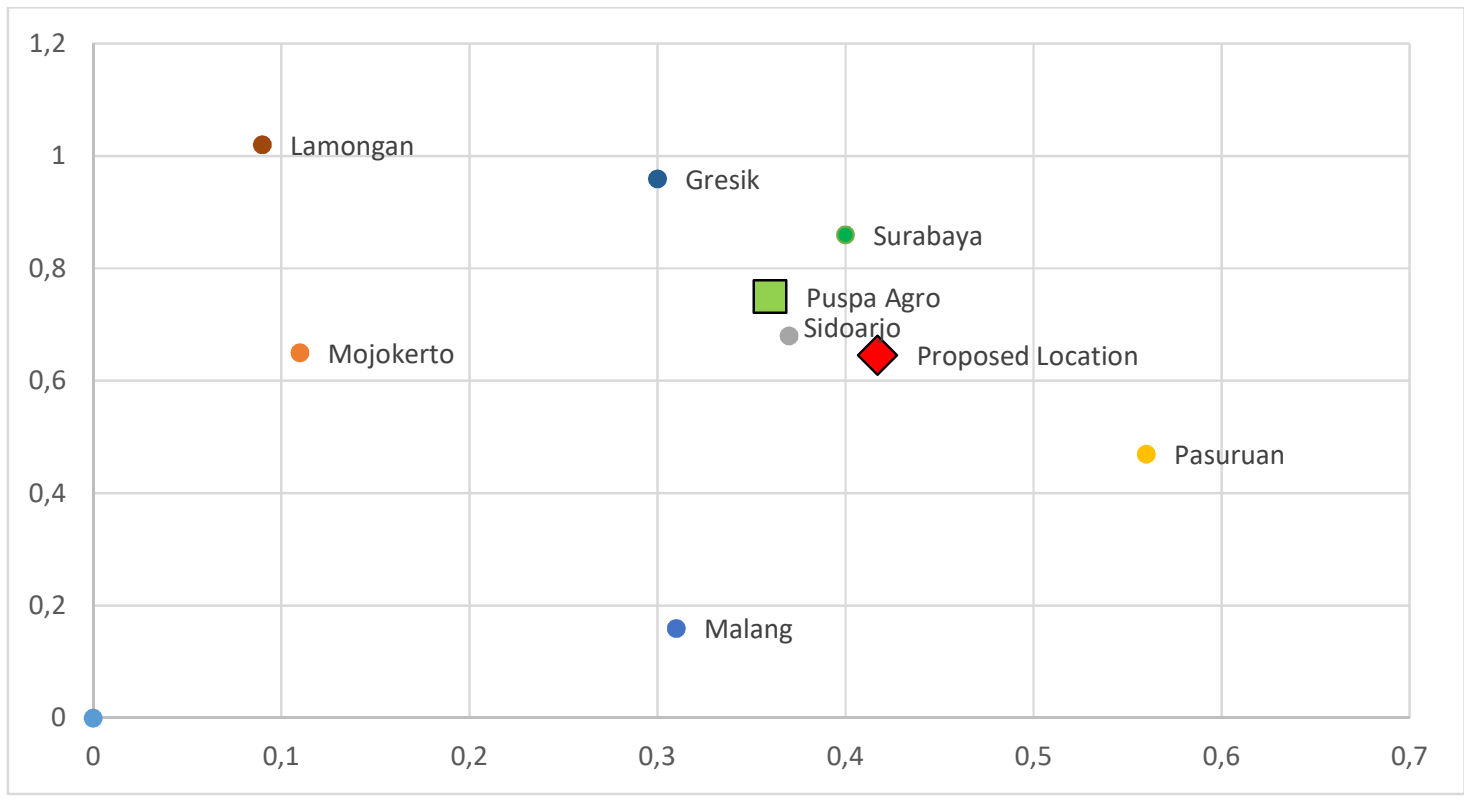

Figure 3. The Proposed Location of Central Market Based on the Number of Population of the Nearest City

The proposed location of central market based on the number of population of the nearest city suggest that the Puspa Agro should be located at Candi East Outer Ring Road in Sidoarjo. This location is very strategic since its closed to the factory and the warehouse along the outer ring road. The proposed location is also near the Tanggul Angin Sidoarjo to Surabaya, Sidoarjo to Malang and Sidaorjo to Pasuruan toll road. 


\section{Conclusions}

The evaluation of the existing Puspa Agro central market can be concluded as follows:

1. The existing location of Puspa Agro central market is not fulfilling the requirements based on three approaches the location of people and goods mobility, The location of agriculture production such as, fishery, fruit and vegetables and The Number of the population of the nearest city.

2. The alternate location must be considered to develop a new central market despite investing on the existing location. The proposed locations are at Waru, Candi Eastern Ring Road in Sidoarjo and area near Pasuruan City.

3. The development of direct access through the toll road toward the Puspa Agro central market had not been fully solve the problem as well as increasing the trading transaction.

4. Converting of the acceleration of the development policy in East Java Province by investing on the profitable and give more benefit for people, not only focus on the Puspa Agro.

\section{Acknowledgements}

Special thanks to our colleagues and Supervisors of the East Java Road Province Agency, for the support of this research.

\section{References}

[1] A. Khisbulloh, "PERANCANGAN DESAIN GRAFIS UNTUK PROMOSI PASAR INDUK MODERN PUSPA AGRO," Jurnal Pendidikan Seni Rupa, vol. 3, no. 1, pp. 165-173, 2015.

[2] R. Ardiyansyah and S. Sugiharto, "ANALISIS PENGARUH BAURAN PEMASARAN TERHADAP MINAT BELI KONSUMEN DI PUSPA AGRO," Jurnal Strategi Pemasaran, vol. 3, no. 2, pp. 1-8, 2016.

[3] C. R. Indraswari and M. N. HR., "PENGELOLAAN KONFLIK AKTIVITAS BISNIS PERSPEKTIF ISLAM PADA MANAJEMEN PASAR INDUK PUSPA AGRO JAWA TIMUR," JESTT, vol. 1, no. 5, pp. 346-362, 2014.

[4] F. Dewi, "BANGSA ONLINE.COM," Bangsa Online, 22 September 2016. [Online]. Available: https://bangsaonline.com/berita/26862/tinggal-5-dari-1045-stan-di-puspa-agroyang-masih-bertahan. [Accessed 5 September 2021].

[5] Redaksi, "ADAKABAR.COM," ADAKABAR.COM, 24 June 2021. [Online]. Available: https://adakabar.com/puspa-agro-rugi-terus-harus-lepas-dari-pt-jgu-agar-fleksibel-kerjasamadengan-pihak-ketiga/. [Accessed 3 September 2021].

[6] D. Bhirawa, "Bhirawa Online," Bhirawa Online, 26 October 2020. [Online]. Available: https://www.harianbhirawa.co.id/pasar-induk-modern-agrobis-puspa-agro-riwayatmu-kini/. [Accessed 1 July 2021].

[7] M. Rosalina, M. and B. Siswadi, "ANALISIS BAURAN PEMASARAN BERAS DI PASAR PUSPA AGRO SIDOARJO," Jurnal Sosial Ekonomi Pertanian dan Agribisnis SEAGRI, vol. 9, no. 2, pp. 1-12, 2021.

[8] M. Madura, "Mata Madura," Mata Madura, 30 January 2017. [Online]. Available: https://matamaduranews.com/puspa-agro-menghabiskan-rp-585-miliar-begini-nasibnya/. [Accessed 2 July 2021].

[9] Kominfo, "KOMINFO," KOMINFO, 18 January 2020. [Online]. Available: https://kominfo.go.id/content/detail/23885/percepatan-pembangunan-ekonomi-jatim-jadikebanggaan-nasional/0/berita. [Accessed 22 July 2021].

[10] B. Cahyadi and B. Aulia, "PENENTUAN TITIK PUSAT WAREHOUSE DAN SISTEM DISTRIBUSI PORTLAND COMPOSITE CEMENT DI WILAYAH WONOGIRI," in Seminar Nasional Sains dan Teknologi (Semnastek), Jakarta, 2018. 
[11] M. R. Iqbal, I. Hasan and A. S. Gusmon, "PENENTUAN LETAK GUDANG UNTUK MEMINIMKAN BIAYA TRANSPORTASI DENGAN PENDEKATAN CENTER OF GRAVITY," Jurnal Manajemen Industri dan Logistik, vol. 4, no. 1, pp. 67-74, 2020.

[12] A. Mawadati, J. S. Purba and R. A. Simanjuntak, "Penentuan Lokasi Fasilitas Gudang dengan Metode Gravity Location Models," Journal of Industrialand Engineering System (JIES), vol. 1, no. 2, pp. 121-126, 2020.

[13] A. U. T. Ama, E. Sediyono and A. Setiawan, "Rekayasa Algoritma Gravity Location Models Untuk Penentuan Lokasi Lumbung Pangan Masyarakat Kabupaten Minahasa Tenggara," Jurnal Teknik Informatika dan Sistem Informasi, vol. 1, no. 3, pp. 194-202, 2015.

[14] N. Djamal, D. Cahyadi and M. P. Setyoko, "IMPLEMENTASI GRAVITY LOCATION MODELSDAN ALGORITMA SAVINGSDALAM MENENTUKAN JARINGAN DISTRIBUSI," Jurnal INTECH Teknik Industri Universitas Serang Raya, vol. 7, no. 1, pp. 7179, 2021.

[15] R. Soesilo, Y. Firmansyah and S. , "PENENTUAN LOKASI EXTERNAL WAREHOUSE DENGAN PENENTUAN LOKASI EXTERNAL WAREHOUSE DENGAN PT. RPZ SURABAYA)," Jurnal Manajemen Industri dan Logistik, vol. 4, no. 1, pp. 58-66, 2020.

[16] W. H. Putri, B. Soedarsono and Y. Wahyuddin, "ANALISIS SPASIAL DENGAN GRAVITY MODEL DAN NETWORK ANALYSIS DALAM PERHITUNGAN NILAI EKONOMI KAWASAN WISATA RELIGI DI KOTA SEMARANG (STUDI KASUS : MASJID AGUNG JAWA TENGAH, SAM POO KONG, DAN MASJID KAPAL)," Jurnal Geodesi Undip, vol. 10, no. 1, pp. 85-94, 2021.

[17] H. B. and R. Jay, Operations Management, 7th Edition, Jakarta: Salemba Empat, 2005. 